\title{
Risk management in construction projects in Somalia
}

\author{
Abdirahman Jibril ${ }^{*}$, Belal A. Shaban ${ }^{1}$ \\ ${ }^{1 *}$ Civil Engineering Department/Graduate Studies Institute/Applied Sciences, Near East University, Nicosia, North Cyprus
}

ARTICLE INFO

\section{ARTICLE HISTORY:}

Received: 07 March 2021

Revised: 21 April 2021

Accepted: 09 May 2021

Published: 25 May 2021

\section{KEYWORDS:}

Construction management, risk analysis, risk management, Somalia

\section{A B S T R A C T}

These days, risk management and analysis are serious issues in the effective management of construction projects, because construction projects are likely to be very dynamic, productive, diverse and increasingly competitive. Risk management helps project parties such as clients, contractors and vendors/suppliers to meet their obligations to reduce negative impacts on their works. The outcomes of the risk management method include the analysis and detection of risks, the creation of building project management systems and the efficient use of resources. The aim of this article is to find out how the Somalian construction companies see the value of construction project risks and how to manage it by dispatching a questionnaire. The total questions of the questionnaire are seventeen questions and were distributed by various participants such as clients, contractors and designers. The findings show that in the implementation of risk management techniques, the Somalian construction industry varies greatly from building companies in foreign countries. The contractor needs to consider risk obligations, dynamics of risk incidents, risk tolerance and risk control skills to handle the risks effectively and efficiently. Due to the insufficiency of experience in the attitude of Somalian entrepreneurs towards risk management is very hard to change. However, as a component of their project management, the construction companies must include risk analysis in projects. The application of risk management in Somalian construction companies is small to moderate, with little difference between organizations' types, sizes and risk tolerances and individual respondents' experience.

\section{INTRODUCTION}

Risk management is a systematic method for defining, assessing and reacting to project threats. It involves optimi zing the risks and effects of adverse events for the goals of the project. Risk is an environmental option rather than a d estiny (Jayasudha et al., 2014). There are many risks associated with construction projects that can have a major impact on the accomplishment of the project. If the construction project meets three fundamental goals, it will be successful: to respect the budget, to respect the completion date and to produce a structure with characteristics at least as good as those originally envisaged (Hamzaoui et al., 2019). Good risk management is necessary to achieve these objectives. The findings of the study are intended to strengthen the risk assessment framework focused on best practices and subsequently, boost the system's overall efficiency and recognize potential initiatives. This approach is strong because, from a knowledge-based point of view, it addresses the role of risk management not in most organisations, is an excellent practice model, which will be built and used as a benchmark for assessment and development and will finally provide an instrument for the analysis of existing risk management functions.

A road was recently constructed in the capital city of Somalia by a general construction company. This article faced months of delay due to weather conditions such as rainfall and incorrect subsurface investigations, total scheduled months were 8 months but ended in 10 months, the scheduled time began on $15^{\text {th }}$ February 2014 and ended on $15^{\text {th }}$ October 2014 , but unfortunately, it ended on $16^{\text {th }}$ December 2014. For the medium length of the construction project, 2-month delay reflects a substantial delay, resulting in a cost increase of $\$ 55,000$ over an initial project cost of $\$ 855,000$ (Somalian currency is Shilin' sh' however, to be 
understood, it has been converted to the US dollar). Fig. 1 contrasts the actual costs with the expected costs; the objective case presented is that it often happens mostly in Somalian construction projects. It is therefore important to extend the risk assessment frameworks that account for all possible sources of risk at different phases of the project. The research discussed in this paper explains this approach for defining risk in construction projects. Every project in Somalia has to do with taking risks, most risks in Somalia Construction Company is over schedule and over budget. Enterprises and organizations should be prepared for potential hazards, most firms tend to take chances at the beginning of activities and, as a result, many are bankrupt at the foundation in the first two years. But there is a very lowrisk tolerance for financial and banking institutions. The aim of the study is to assess the causes of risks in Somalian construction companies, to assess and identify the risk that is commonly found in Somalian construction companies and to assess the most important fields for strengthening risk control.

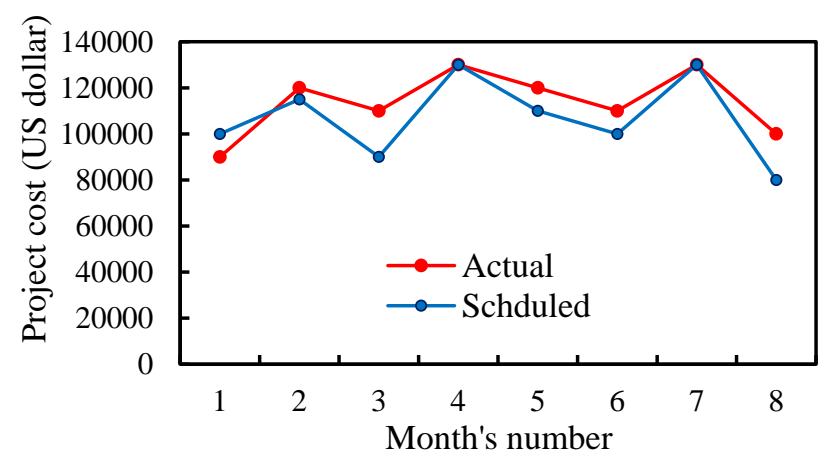

Fig. 1. Comparison of actual and planned project costs (monthly costs)

\section{FINDINGS}

Risk management for construction projects in the construction supply chain is poor, inconsistent and incomplete (Tah \& Carr, 2001). Group partners often have no common awareness of group vulnerability and are not willing to incorporate proactive early alert and prevention steps to resolve problems resulting from decisions taken elsewhere in the network efficiently (Tah \& Carr, 2001). Both the construction and construction industries, in general, are risky (Zavadskas et al., 2010). The risk can be explained in terms of an event that impacts targets and can produce a positive or negative result in micro-, meso- and macro environments. Risk management is a system that aims at determining and quantifying all risks to which a company or project is exposed, in order to make an informed decision on how to manage risks (Markmann et al. 2013). PMBOK lists risk management as a focus for project management in nine areas and explains this as a systemic process for the identification, analysis and response of project risks. The project was classified into three groups, namely building finances, construction time and construction design, by Abdou (1996). Based on a survey questionnaire with industry practitioners, Shen (1997) identified eight key project delay risks and ranked them. The risks that engineering/construction services providers usually face in a foreign country have been identified Ramcharran (1998), and the risk specific to the developing countries has been further identified by Kalayjian (2000). Haarmeyer and Mody (1997), in particular countries like Guinea and Mexico, explained the main risks. The main characteristics of the developing countries have been described by Jaselskis and Talukhaba (1998) and top information needs have been identified in five key areas for architectural, technical and constructive enterprises.

External risks are those risks that go beyond the manager of the task management team. The external risk was divided into political risk; social risk; and climate risk. Political risk is the adaptation of the structure of laws, rules, strategy and mismanagement by the government (Li \& Liao, 2007). Economic risks are the inconstancy of the economy in the region, the degree of compensation for production, inflation and financing.

\section{METHODOLOGY}

A literature review is presented about risk in construction companies in Somalia. The sources have mainly been referred to books, conferences, academic research and theses. The main tool was used to collect the data and to achieve the objective of the research is a questionnaire survey.

The questionnaire included a set of questions to find out how the Somalian construction company sees the value of construction project risks and how to manage them. Every question of the questionnaire's questions was explored through several previous studies.

The questionnaire employed a Likert scale of 1-5. A scale Likert is a form of a questionnaire on a psychometric response scale and is the scale most frequently used in the study. Respondents demonstrate their level of agreement with the claims when answering a questionnaire by Likert. The respondents had to indicate the relative critical/effectiveness of increasing risk factor likelihood and its management effects.

\section{RESULTS AND DISCUSSIONS}

Table 1 shows the majority of participants are male and females are the lowest of the participants' population. $94.6 \%$ of participants are male, and $5.4 \%$ are female. In fact, that's good to be a variety in participants. 
The majority of participants' age is 35-45 it performs $40.5 \%$ of total participants, and $27 \%$ of participants age is $45-55$, and $18.9 \%$ of participants age is 55 and above, and in last $13.5 \%$ of participants' age is $25-35$.

Table 1 shows that $16.2 \%$ of participants experience are less than 1 year, $21.6 \%$ of participants experience are 1-4 years, $24.3 \%$ of participants experience is between 4 up to 6 years, $24.3 \%$ of participants experience is between 6 up to 10 years, $13.5 \%$ of participants experience is more than 10 years, the generality of participants experience is between 4 up to 6 years and 6 to 10 years.

Table 1. Demographic data

\begin{tabular}{|c|c|c|c|}
\hline $\begin{array}{l}\text { Demographic } \\
\text { data }\end{array}$ & Categories & Frequency & $\begin{array}{c}\text { Percent } \\
\%\end{array}$ \\
\hline \multirow[t]{2}{*}{ Gender } & Male & 35 & 94.6 \\
\hline & Female & 2 & 05.4 \\
\hline \multirow{4}{*}{ Age } & $25-35$ & 5 & 13.5 \\
\hline & $35-45$ & 15 & 40.5 \\
\hline & $45-55$ & 10 & 27.0 \\
\hline & 55 and above & 7 & 18.9 \\
\hline \multirow{5}{*}{$\begin{array}{l}\text { Experience in } \\
\text { field }\end{array}$} & $<1$ & 6 & 16.2 \\
\hline & $1-4$ & 8 & 21.6 \\
\hline & $4-6$ & 9 & 24.3 \\
\hline & $6-10$ & 9 & 24.3 \\
\hline & More than 10 & 5 & 13.5 \\
\hline \multirow{4}{*}{$\begin{array}{l}\text { Education } \\
\text { level }\end{array}$} & High School & 5 & 13.5 \\
\hline & Bachelor Degree & 23 & 62.2 \\
\hline & Master Degree & 5 & 13.5 \\
\hline & $\begin{array}{c}\text { Vocational } \\
\text { Training }\end{array}$ & 4 & 10.8 \\
\hline \multirow{5}{*}{ Position } & Manager & 5 & 13.5 \\
\hline & Vice Manager & 7 & 18.9 \\
\hline & Project Manager & 7 & 18.9 \\
\hline & Site Engineer & 10 & 27.0 \\
\hline & Office Engineer & 8 & 21.6 \\
\hline
\end{tabular}

Table 1 shows that $13.5 \%$ education level of participants is high school level, $62.2 \%$ education level of the participants have a bachelor degree, $13.2 \%$ education level of participants have a master degree, $10.8 \%$ education level of participants is only vocational training. The overall majority of participant's education level is a bachelor degree.

The position of participants is varied, Table 1 shows that $13.5 \%$ of participants are managers, $18.9 \%$ of participants are vice managers, $18.9 \%$ of participants are project managers, $27 \%$ of participants are site engineers, $21.6 \%$ of participants are office engineers, the generality of the participants is site engineer.

Table 2 shows that the mean of item \#5 "Complicated part in risk management procedure in Somalian construction company" equals 4.44 (88.77\%), Test-value $=13.04$, and $\mathrm{P}$ value less than 0.05 . It is concluded that the respondents agreed to this item. The mean of item \#12 "The construction participants in Somalia" equals 2.89 (57.85\%), Test-value $=$ -1.19 , and P-value $=0.25$. which is greater than the level of significance 0.05 . It is concluded that the respondents (Do not know, neutral) to this item. The mean of the total equals $3.64(72.88 \%)$, Test-value $=9.29$, and P-value less than 0.05 . The sign of the test is positive, so the mean of this field is significantly greater than the 0.05

Table 2. Mean and test values

\begin{tabular}{|c|c|c|c|c|c|c|}
\hline Item & Mean & S.D. & $\begin{array}{l}\text { RII } \\
(\%)\end{array}$ & $\begin{array}{c}\text { Test } \\
\text { value }\end{array}$ & $\begin{array}{c}\text { P- } \\
\text { value }\end{array}$ & Rank \\
\hline $\begin{array}{l}\text { Knowledge of } \\
\text { risk } \\
\text { management } \\
\text { in the project }\end{array}$ & 4.29 & 0.98 & 85.75 & 11.24 & 0.000 & 2 \\
\hline $\begin{array}{l}\text { Role of } \\
\text { participants } \\
\text { in the project }\end{array}$ & 3.85 & 0.91 & 76.99 & 7.99 & 0.000 & 5 \\
\hline $\begin{array}{l}\text { Number of } \\
\text { workers in } \\
\text { the } \\
\text { Construction } \\
\text { Company }\end{array}$ & 3.95 & 0.85 & 78.9 & 9.52 & 0.000 & 4 \\
\hline $\begin{array}{l}\text { How } \\
\text { participants } \\
\text { deal with } \\
\text { project risk }\end{array}$ & 3.78 & 0.93 & 75.62 & 7.16 & 0.000 & 7 \\
\hline $\begin{array}{l}\text { Complicated } \\
\text { part in risk } \\
\text { management } \\
\text { procedure in } \\
\text { Somalian } \\
\text { construction } \\
\text { company }\end{array}$ & 4.44 & 0.94 & 88.77 & 13.04 & 0.000 & 1 \\
\hline $\begin{array}{l}\text { Risk } \\
\text { management } \\
\text { model }\end{array}$ & 3.85 & 0.89 & 76.99 & 8.13 & 0.000 & 6 \\
\hline $\begin{array}{l}\text { Most } \\
\text { influenced } \\
\text { development } \\
\text { of risk } \\
\text { management }\end{array}$ & 3.14 & 0.73 & 62.74 & 1.60 & 0.11 & 9 \\
\hline $\begin{array}{l}\text { Knowledge } \\
\text { area which is } \\
\text { helpful to } \\
\text { manage risk } \\
\text { in Somalian } \\
\text { construction }\end{array}$ & 3.64 & 0.79 & 72.88 & 6.98 & 0.000 & 8 \\
\hline $\begin{array}{l}\text { General } \\
\text { approach to } \\
\text { managing } \\
\text { construction } \\
\text { risk in } \\
\text { Somalia }\end{array}$ & 3.96 & 0.96 & 79.18 & 8.5 & 0.000 & 3 \\
\hline $\begin{array}{l}\text { The risk of } \\
\text { your project } \\
\text { is the most } \\
\text { frequent }\end{array}$ & 2.9 & 0.67 & 58.08 & -1.22 & 0.23 & 11 \\
\hline $\begin{array}{l}\text { Fence to risk } \\
\text { management } \\
\text { practice in } \\
\text { Somalian } \\
\text { construction } \\
\text { company }\end{array}$ & 3.03 & 0.74 & 60.55 & 0.31 & 0.75 & 10 \\
\hline $\begin{array}{l}\text { The } \\
\text { construction } \\
\text { participants } \\
\text { in Somalia }\end{array}$ & 2.89 & 0.71 & 57.85 & -1.19 & 0.25 & 12 \\
\hline Total & 3.64 & 0.59 & 72.88 & 9.29 & 0.00 & $2-12$ \\
\hline
\end{tabular}

https://www.londontechpress.co.uk 


\section{CONCLUSIONS}

Risk identification is the most difficult one of the risk management process, an effective process of risk management encourages a construction activity to recognize and measure risks and think about policies to reduce risks. Construction undertakings managing risk efficiently and effectively benefit from financial and efficiency saving, improved new project performance and better decision-making. Risk management is a comprehensive and systematic approach to the identification, analysis, and response to risks in order to achieve project objectives in the context of construction project management.

The findings show that in the implementation of risk management techniques, the Somalian construction industry varies greatly from building companies in foreign countries. The contractor needs to consider risk obligations, dynamics of risk incidents, risk tolerance and risk control skills to handle the risks effectively and efficiently. Due to the insufficiency of experience in the attitude of Somalian entrepreneurs towards risk management is very hard to change. However, as a component of their project management, the construction companies must include risk analysis in projects. The application of risk management in Somalian construction companies is small to moderate, with little difference between organizations' types, sizes and risk tolerances and individual respondents' experience. The study should help management to identify activities where time and financial aspects are at risk and thus provide a basis for management to make objective risk reduction decisions at the agreed level. The study should support risk management construction projects in Somalia. These results are essential for the introduction of more successful steps to ensure that future progress is pushed in the right direction. Risk management is a key method for assessing the project.

For future research, further questions concerning risk management can be improved by evaluating and identifying. In addition, a model that could be used to test the risk management standard in the Somalian construction companies can be strengthened through research.

\section{REFERENCES}

[1] Abdou, O. A. (1996). Managing Construction Risks. Journal of Architectural Engineering, 2(1), 3-10. https://doi.org/10.1061/(ASCE)10760431(1996)2:1(3)

[2] Haarmeyer, D., \& Mody, A. (1997). Private capital in water and sanitation. Finance and Development, 34(1), 34-37.

[3] Hamzaoui, F., Amine Allal, M., Taillandier, F., \& Achoui, M. (2019). Risk management in construction projects by coupling the SMACC agent with the MADS
MOSAR method-application to the dam project in Mascara, Algeria. International Journal of Construction Management, 1-15. https://doi.org/10.1080/15623599.2019.1641890

[4] Jaselskis, E.J. and Talukhaba, A. (1998) Bidding operations in developing countries. Journal of Construction Engineering and Management, 124(3), 185-93.

[5] Jayasudha, K., Vidivelli, B., \& Gokul Surjith, E. R. (2014). Risk Assessment and Management in Construction Projects. International Journal of Scientific \& Engineering Research, 5(8), 387-396.

[6] Kalayjian, W. H. (2000). Hidden Risks of Construction in the Third World. In Construction Congress VI: Building Together for a Better Tomorrow in an Increasingly Complex World, 1126-1135. https://doi.org/10.1061/40475(278)122

[7] Li, Y., \& Liao, X. (2007). Decision support for risk analysis on dynamic alliance. Decision support systems, 42(4), 2043-2059.

[8] Markmann, C., Darkow, I.-L., \& Von Der Gracht, H., (2013). A delphi-based risk analysis - identifying and assessing future challenges for supply chain security in a multi-stakeholder environment. Technological Forecasting and Social Change, 80(9), 1815-1833. http://dx.doi.org/10.1016/j.techfore.2012.10.019

[9] Ramcharran, H. (1998) Obstacles and opportunities in international engineering services. Journal of Management in Engineering, 14(5), 38-46.

[10] Shen, L. Y. (1997). Project risk management in Hong Kong. International journal of project management, 15(2), 101-105.

[11] Tah, J. H., \& Carr, V. (2001). Knowledge-based approach to construction project risk management. Journal of computing in civil engineering, 15(3), 170177. https://doi.org/10.1061/(ASCE)08873801(2001)15:3(170)

[12] Zavadskas, E. K., Turskis, Z., \& Tamošaitienè, J. (2010). Risk assessment of construction projects. Journal of Civil Engineering and Management, 16(1), 33-46. http://dx.doi.org/10.3846/jcem.2010.03 